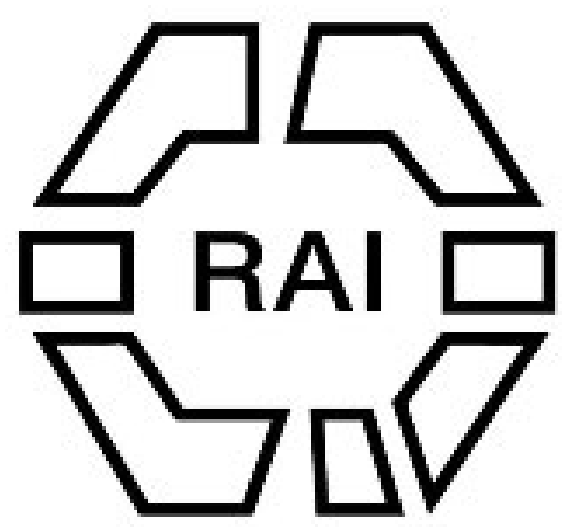

The Natives of Borneo. Part II

Author(s): Brooke Low and H. Ling Roth

Source: The Tournal of the Anthropological Institute of Great Britain and Ireland, Vol. 22 (1893), pp. 22-64

Published by: Royal Anthropological Institute of Great Britain and Ireland

Stable URL: http://www.jstor.org/stable/2842111

Accessed: 15/06/2014 21:05

Your use of the JSTOR archive indicates your acceptance of the Terms \& Conditions of Use, available at http://www.jstor.org/page/info/about/policies/terms.jsp

JSTOR is a not-for-profit service that helps scholars, researchers, and students discover, use, and build upon a wide range of content in a trusted digital archive. We use information technology and tools to increase productivity and facilitate new forms of scholarship. For more information about JSTOR, please contact support@jstor.org. 
From the École d'Antrhopologie de Paris.-Revue Mensuelle. 1892. No. 2.

From the Edrror.- - Nature. Nos. 1163, 1164.

Revue Scientifique. Tom. xlix, Nos. 7, 8.

From the Niederlausitzer Gesellschaft für Anthropologie und Urgeschichte.-Mittheilungen. Band ii. Heft 3.

From the Royal Societr of Victoria.-Proceedings. Vol. iii.

Transactions. Vol. ii. Part 1. Vol. iii. Part 1.

From the Sociedade Carlos Ribeiro.-Revista de Sciencias Naturaes e Sociaes. Vol. ii. No. 7.

From the Sociedade df Geographia dF Iismon.-Boletim. 10A Serie. Nos. 1-3.

From the Société Impértais des Natrtralistes de Moscou.Bulletin. '1891. Nos. 2 and 3.

From the Socilet of ArTs.-Journal. Nos. 2047, 2048.

Mr. H. Ling Roth read a paper on "The Superstitions, Burial, and other Customs of the Natives of Borueo. Part II. (Edited from the papers of the late H. Brooke Low)."

Mr. F. W. Rudler, Mr. A. L. Lewis, and Mr. G. M. Atkinson took part in the discussion.

The Natives of Borneo. Edited from the Papers of the late Brooke Low, Esq., by H. Ling Roth.

II. Land Tenure and Cultivation; Habitations; Slaves; Dress, Personal Ornament and Fashionable Deformity; Hunting ; Fishing ; Na vigation ; Weapons and War-dress ; Aggressive Warfare ; Defensive Warfare, Heads ; Captivfes; Cannibalism; Musical Instruments AND SINGING.

\section{1.-Land Tenure and Cultivation.}

As regards the tenure by which land is held, it has been the immemorial custom that when a person fells the virgin forest, he acquires by that act a perpetual title to the land. It is his from henceforth to do with as he pleases; he may sell it, or lend it, or let it. The rent he is empowered to demand may not exceed in value a dollar, and must be either a game-cock, or a suckingpig, or a couple of plates. But as land is rising in value every year, and old jungle is becoming scarcer and scarcer, there is a 
marked tendency among the tribes to demand a heavier rentin fact several dollars a year. The tenure, too, has been modified within late years in view of the increasing demand for accommodation, and it is now generally understood that when the proprietor chooses to leave the district and remove into a distant country he forfeits, by so doing, all title to the ground and can no longer exact rent.

Agriculture with the Sea Dyaks is in a very backward condition, but they contrast very favourably with the Malay population in the vicinity. Neither use the plough nor buffalo, but the former cultivate on a more extensive scale and with a more provident idea. They grow, both individually and collectively, far more than they require for their own consumption, and with the residue they purchase necessaries, such as salt, steel, iron, and luxuries, such as personal ornaments, for their families. If the harvest has been really plentiful they are even able to afford to purchase gongs and toddy, and perhaps a jar or two.

As a rule they prefer to cultivate hilly soil, but some few have learnt to utilize the wet land. Their farming operations are regulated by the position in the heavens of the Seven Stars of the Pleiades. They commence business towards the end of the dry season, July and August, so that they have the wet monsoon to bring the paddy to maturity, and the beginning of the following fine weather, April and May, to ripen the grain.

The old jungle is called kampong, and the new is called temuda. The Dyaks prefer infinitely to farm the former whenever it is to be obtained within reasonable distance of the village, and when it is getting scarce in their immediate neighbourhood, they shift their residence nearer to it. In parts of the country more populous than others, it frequently happens that the Dyaks have not in their territory any old jungle; such situations are not so laborious to prepare, but being destitute of the rich layer of vegetable mould and the fertilizing properties of burnt wood, are not nearly so productive. After having felled the old jungle and farmed on it once, they leave it for seven years to grow up again and are then ready to use it a second time. The first year's growth is called kruaoh.

When it is intended to open out new country, the first thing to be done is for every family to select an eligible piece of forest land and to mark out the quantity they wish to cultivate. The next step is to beburong, that is to say to consult the omen birds of the tribe to learn whether or no they approve of this choice. For this purpose they erect a hut first in one quarter then in another of the land in question, and wait upon the birds for 
three days in succession until they hear either a note of warning to keep away from it, or a note of encouragement to remain on it. If the auguries are favourable they proceed to denude the land of its forest. Both sexes share in this labour; the women and boys clear away the undergrowth and the men fell the trees. Much valuable timber is then destroyed, as they spare only such fruit trees as are in full bearing, and those upon which the bees settle and from which they expect to be able to gather wild honey. As some of the trees are of enormous girth being furnished with buttresses, they do not always fell them at the base, but more often some distance up the trunk; others they leave standing altogether, merely lopping off the boughs to feed the fire which is afterwards to lay bare the ground and manure the soil.

When the land has been fully cleared it is left to dry. Sun and wind are now of almost vital consequence to the Dyaks, for if they are unable to thoroughly burn this immense mass of timber, famine stares them in the face for the year to come. If it pour with rain day after day and week after week, and there is no promise of continued fine weather, they are apt to imagine that some impurity has defiled the tribe and that the face of the Great Spirit is hid from them. So the elders of the people get to work to find it out, and adjudicate on all cases of incest and bigamy, and purify the earth with the blood of pigs. Prayers are offered to Betara from one end of the country to the other ; for the space of three days the villages are tabued, and all labour is discontinued; the inhabitants remain at home, and strangers are not admitted. But if the weather is warm and dry the farms are ready in a very few days for the burning. They are set on fire from the windward side when the breeze is blowing, and soon the entire mass is seething with flames. It is a magnificent spectacle to behold when several of these farms are ablaze at once, and the hills are flaring like volcanoes. The heat at this season caused by the universal burning is almost insupportable; for days not a glimpse is to be caught of the blue sky overhead; the smoke hangs over the country like a heavy cloud, and the sun glows through the fog like a globe of molten copper.

When the fire has exhausted itself and the ground is again cool, which it soon is from the frequency of rain in this country, they commence to sow the seed. The men traverse the farm with dibblers in their hands and dibble the ground; the women follow and drop in the paddy seed and cover up the holes by scraping earth into them with their feet. Indian corn (lingkau) is planted sparingly at the same time; and as it is ripe and off the ground within three months from the date of the sowing, it does not 
injure the paddy, amongst the rows of which it is sown; and as it comes in at a season when the rice with some is getting exhausted, and the second crop is not ready, it is of great use to the Dyaks, though not so much esteemed as rice as an article of food. On the larger ccllection of ashes they also sow the seeds of gourds (gerrole), pumpkins (entekci), a kind of melon without flavour (junggat, kundu), and cucumbers (rampu), of which they are very fond. These trail along the ground amongst the stems of the paddy, to which they appear to do no injury, and continue bearing for some time after the rice-crop has been gathered in. A small quantity of pulut is also grown by every family. It is a fine strong growing kind of paddy, but when cleaned and boiled is of a peculiar clammy nature. It bears a higher price than any other kind in the market, and is always eaten by the Dyaks cooked in green bamboos, as it is thought that the ordinary metal cooking pot spoils the fiavour. The farm is tabued during the tugal.

After the seed has been sown, it is the business of the men to plant a fence (raja) round the farm to protect it from the inroads of wild animals such as pig and deer; this should not occupy much time, as the material is ready to hand, having been collected for the purpose previous to the burning, from the débris scattered on the ground.

There are many things which sorely try the patience of the Dyaks as they watch with unflagging interest the growth of their crops. It is true the pigs and deer are excluded by means of the wooden fence, but nothing short of the most untiring vigilance, and not always even that, can keep out the numerous climbing and winged pests, such as nonkeys, squirrels, rats, and sparrows, some of which are sure to visit the farm as the paddy is ripening. Their sole remedy, such as it is, is to give a feast and propitiate the spirits in the usual manner. A miniature junk is built and filled with delicate morsels, the plagues are then besought to embark for some other country, and the toy is set adrift to float out to sea with the outward tide. During this ceremony the village is tabued for seven days in the same manner as is done when the purification for burning is performed.

The next thing is to build a langkan or farm house on some commanding or central situation where the family may reside without inconvenience off and on or altogether just as they please until the harvest is over. They have still weary duties to perform before they can hope to reap the fruit of their toil; but it too often happens that these are left to the women and children, while the able-bodied men seek other and more congenial occupation, i.e., either follow a war-path, or journey 
into the far interior, or plunge into the jungle in quest of its produce.

As a rule the women have to do all the weeding (mantun) by themselves; this is a very laborious task, as the weeds grow so rapidly as to threaten to choke the paddy unless promptly removed. Another grievance is the grass, originally called rumput teka, but since nicknamed rumput blanda, and which they declare was introduced by the whites to feed their cattle on. It is now a proverbial saying with them that it is impossible to get rid of this grass, likewise is it unprofitable to shake off the rule of the white man.

As the paddy begins to ripen, the men return to their homes and the families remove entirely to their farms, where there is plenty to do to scare away the birds and other pests and to prepare for the harvest. The paths intersecting the farm are closed at this season, and no one can traverse them without paying a penalty or sin-offering of a fowl and a bit of iron. Those who may be suffering from positive want, having exhausted their last year's stock, now glean of the half ripe paddy as much as they require for their immediate necessities; this is called numbar.

But when the paddy is fully ripe they all turn out, men and women, boys and girls, with knives and baskets and pluck the ripe ears with a few inches of stalk; these are then carried home and put out to dry, after which they are thrown into an enormous sieve suspended from the roof of the house, and threshed by the action of the feet, the grains falling through on to a mat placed underneath on purpose to receive them. After thorough drying in the sun, they are put in tubs made of bark (tibang) and stowed away in the loft or else housed in a liut, built on purpose for them hard by the village, the posts of which are furnished with wooden discs immediately below the flooring to prevent the rats from entering. The Dyak method of pounding the paddy to free it from the husk by means of pestle and mortar is injurious to the grain. By it the hard outer skin which protects it from the weevil is broken and this insect soon takes advantage of the circumstance to attack and destroy it. In the husk or paddy state the rice can be kept for years without injury.

The Punans and Kajamans farm meagrely; they prefer the sago to rice and grow the palm.

\section{Hab̈rtations.}

A Sea Dyak village is a terrace upon posts varying in length according to the number of houses of which it is composed, and 
as the various houses are built according to a single scale and measurement and by a combination of labour, they rarely fail to present a uniform and regular appearance. ${ }^{1}$

There is always a ladder at either end of the terrace by which to ascend and sometimes one or more towards the centre of the tanju or open air-platform. The roof is thatched throughout with the same material - shingles or palm leaves-if the latter the nipa (daun apong) leaves are used where procurable, and where not (daunbira) the pandanus. The flooring in some villages is made of palm trees split into laths (nibong $=$ wild varieties of the areca); in other cases of cane or bamboo or even twigs. The laths of split barnboo allow a delicious current of air to permeate the apartment. The outer walls are of plank, the inner of bark. No nails are used, the beams or rafters are lashed together with rattans or secured by wooden pegs. The posts are innumerable and of hard wood. The village is surrounded at its base by a wooden palisade which is itself protected by chevaux cle frise of pointed bamboo. The village is divided by a plank walling into two main portions, the front and the rear. The former partakes of the nature of a very wide verandah and is open throughout its entire length. The latter occupies the rear of the entire building and is sub-divided into apartments, one for each family. Between the plank wall and the edge of the ruai is the tempuan or footway, a narrow passage running through the centre so that a person may walk from one end of the village to the other without encountering any obstacles.

Every family thus possesses a compact little residence to themselves comprising a bilieh or room where tiley can enjoy privacy when they like, a tempuan or thoroughfare where they pound their rice and pile up their firewood, a ruai or verandah where they receive visitors, a tanju or open-air platform where they air their things and lounge in the cool of the evening, and a sadau or loft where they keep their tools and store their paddy.

The bilieh or private apartment is furnished with a swinging door which opens outwards and is closed by means of a heavy weight suspended to a thong to the inside. The door can be secured when required by means of a bar. If the room be unusually large, it may have two doors for the sake of convenience. Figures are sometimes carved or painted on the door-saurians among others, grotesque images of supernatural beings, and indecent caricatures of the human person. There is no window such as we understand, but a portion of the roof is so constructed that it can be raised a foot or two by means of a stick to let

1 K:ñah houses are packed close together and there are originally three in a row without any intermediate space. The floor is only four feet from the ground, and any one can jump ir. 
out the smoke or to admit the fresh air. If the neighbours are near relations or intimate friends, as is often the case, a hole is cut in the wall which separates the room to avoid the necessity of a roundabout way into one anothers' apartments, and some villages are so arranged that one can traverse the entire length of the rear section of the building by means of these apertures without appearing on the verandah at all. There is no furniture in the room-none in fact being required. The floor is the occupiers' table and they squat to their meals. But there are plenty of mats to sit upon andi baskets to pack their clothes in. Their cups and plates are hung in rows upon the walls as much for ornament as for use. Their valuables, such as old jars, gongs, etc., are ranged on three sides so as to present the most imposing appearance of wealth.

But the room is stuffy and untidy, and no wonder, seeing that there is but one for exch family and this one is used as a kitchen as well as a mess room, as a nursery as well as a bed chamber. There can be no absolute privacy unless the door is barred to exclude the neighbours. Boys and girls keep running in and out and the dogs are always on the watch in the tempuan to spring in whenever the door swings open. The floor is swept after a fashion but the room is never deserted, and the roof is simply black with soot. The refuse is thrown into the piggery and poultry yard, which occupies the area or waste space under the house. Very little stench, if any, reaches the apartment from the ground, as the floor is raised too high above it to be affected by it. The dapur or fire-place is the only real piece of furniture in the room. It is built either to the right or to the left of the door set up against the wall of the tempuan and resembles an open cupboard, the lowest shelf resting upon the floor and the upper shelves being of lattice work instead of plank. The former is boarded all round and filled with clay. This is the fireplace and it is furnished with a few stones between which the pots are set. The shelf immediately above the fire is set apart for smoking fish and meat, etc. The shelves above this again are filled with firewood which being thoroughly dried is ready for use. The women, who do all the cooking, have also to keep these shelves supplied from the pile in the tempuan. As the smoke from the wood fire is not conducted to the roof by means of a chimney it spreads itself throughout the loft and blackens the beams and rafters until it finds its way out by the open window. ${ }^{1}$

1 Elsewhere B. L. says : "They make a palan or raised platform and under it light a fire and heap it with dry twigs and fill the platform with split wood for drying as bekal (firewood). From the fire they take brands for other fires. They drive three pegs into the ground and place prion (jar) on top, fill 
The tempuan or general thoroughfare is between the bilieh and the ruai. It is three feet in width and is paved with wood. It is furnished with a ladder or notched stick by which to reach the loft, a family mortar where the women pound their paddy with wooden pestles to free it from the husk, and a pile or two of firewood reared by the men for use inside. This passage is also used by the women to winnow their rice in, feed their dogs, and attend to their chickens, and by the men to wash the dirt off their feet when they come home from their work. The wall of the tempuan is sometimes elaborately painted in various patterns, and the spears of the family are thrust into the skirting board so as to be handy.

The ruai or verandah is in front of the tempuan and is as nearly as possible the same size as the bilieh from which it differs principally in being open on all sides and without any partition. It is therefore a cooler and more agreeable place and as such is frequented by both sexes for the purposes of conversation, discussion, and indoor pursuits. Female visitors are usually received in the bilieh, but male visitors are invariably received in the ruai and only enter the bilieh when invited to do so to be introduced to the women and to share the meals. They sleep in the ruai along with the boys and bachelors, and sit there all day when they have nothing better to do, conversing with the head of the family and chewing betel. The floor is carpeted with thick and heavy mats of cane interlaced with narrow strips of beaten bark. Over these are spread other mats of thinner and finer texture. There is a small fireplace between this and the next ruai for the men to warm themselves at when they get up, as they usually do, in the chill of the morning, before the sun has risen above the trees; the fire is allowed to go out in the middle of the day, but is revived towards the evening when it is getting dark, but still too early to light the torches.

Some ruais are provided with a panggan or bedstead with plank sides in one corner of the room for the men to sleep in, but this is not always the case. If the head of the family has made it for his own use and if he be a chief or rich man he will fix his gongs of various kinds around it for the sake of show; his weapons will be within reach and his war dress will hang from the roof where it can be seen to best advantage - a skull cap of wickerwork with its nodding plumes, and a skin jacket decorated with the tail feathers of the war bird of the tribe. But the most valuable ornament in the ruai by far is

quarter with rice and fill up with water and when it simmers corer it with leares. Before the arrival of Europeans the Dyaks used earthen prions made by themselves." 
of course the bunch of human heads which hangs over the fireplace like a bunch of fruit; these are the heads obtained on various warpaths by various members of the family, dead and living, and are handed down from father to son as the most precious heirlooms, more precious even than the ancient jars which they prize so lighly. The next ornament of paramount importance is the bag of charms which is fastened to the centrepost and which is in like manner handed down from generation to generation and about which there is a great to do if any of the charms are lost or stolen. ${ }^{1}$ Other posts are often adorned with trophies of the chase, horns and such like of deer and wild cattle and the heads of animals such as bears, monkeys, and crocodiles killed by the young boys. The empty sheaths of the swords and knives of the family are suspended on wooden hooks, while the naked blades are placed in racks above their heads.

The tanju or open-air platform is in front of the ruai and is railed at the edge, but the rail is often so slight that it is unsafe to lean against it. The flooring is usually of ironwood the better to stand exposure to the weather. It is used as a lounge in the evening, the view from it being extensive and the breeze refreshing. While the sun is shining the paddy is put out to dry as are the clothes and a variety of other things. The family whetstone and dye vat are kept here under the eaves of the roof.

The sadcu or loft is used to stow away the baskets and agricultural instruments during the season they are not in use. The paddy is stowed away here in tubs of bark and also the seed for next year's farm. ${ }^{2}$ Young women often sleep here and so do the young men and boys who are unprovided with curtains when the mosquitoes and sandflies are troublesome down below. They burn a fragrant bark to keep off the mosquitoes.

Whenever it is deemed expedient by the Sea Dyaks to shift from one locality to another, or to abandon an old habitation in favour of a new one, a general meeting is convened to consider the proposition and the desirability of the measure is fully discussed. $^{3}$ If a move be decided upon a few experienced men

1 While on the Rejang river "a Kanowit gave me the tusk of a crocodile which devoured his sister, and showed me a boar's tusk which was lost to his f.amily by an uncle who was killed by a Ukiet and to recover which he a few years ago killed the Ekiet. He showed me another tusk which was dropped by one of the boars which attacked and destroyed the house of an ancestor Jiving at Lakut." Articles like these appear to constitute their charms.

2 The Krans, Kiñahs, and Lanahans stow itheir paddy in barns built for the purpose. The floor is six feet above the greund, and the posts are encircled with circular wooden dises to keep off the rats.

3 The Kiñahs move away every few years so as to be always near heavy bush which they prefer for their farms. 
are deputed to select a site and to report on its adaptability. If there be no reason to be dissatisfied with the choice, others are sent to hear whether the birds they venerate are for it or against it. Three days in succession they visit the spot and if the bird omens be favourable they proceed to work at once, and on the following morning the men turn out in a body with axes and choppers to hew down the jungle which is then left to dry. Another general meeting is thereupon convened to determine the question of the tuah or chieftainship, the measurement of the timbers, and the sequence of therooms. It is customary to place the richest people in the centre of the village that they may exercise hospitality to all comers, and the boldest at either extremity so that they may defend the approaches if called upon to do so. The next move is to appoint an evening for the people to meet at the site of the new village. The ground is then cleared and measured out and pegs are put in where the posts are to stand. A piece of bamboo is then stuck in the ground, filled with water and the aperture covered with leaves, a spear and a shield are placed beside it, and the whole is surrounded by a rail. The rail is to protect the bamboo from being upset by wild animals and the weapons are to warn strangers not to touch it. If there is much evaporation by the morning the place is considered hot and unhealthy and is abandoned. Half-a-dozen people or so remain to keep watch and beat their tomtoms all night to frighten away evil spirits. Their friends return early in the morning and if all is well they set to and dig the holes, commencing with the chief's quarters and working sinuultaneously to left and right of him. Every family must kill a fowl or a pig before the holes san be dug, and the blood must be sineared on the feet and sprinkled on the posts to pacify Pulang Ganc the tutelary deity of the earth. The posts must be planted firmly, for if one were to give way subsequently it would be regarded as a disastrous svent and the house would be abandoned. All combine to labour collectively until the skeleton of the village is complete, and then every family turns its attention to its own apartments. When the building is sufficiently advanced to receive them they pack up their valuables and convey them by water if practicable, halting on the way until they obtain a favourable omen when they proceed rejoicing. Their valuables and cotton stuffs may not be moved into the house before themselves, they must be taken with them; this is required by custom. Before the village can be occupied a pig must be killed and its entrails examined and if the reading be unsatisfactory it is abandoned. After everything is settled a cup of tuck (toddy) is passed round.

When a family proposes to leave the village and remove else- 
where it must give an ensilan (propitiatory gift ?) or be responsible for the consequences if a death ensue; a fowl, or a bit of iron, or a pig if the village be a large one is usually given.

When a person dies the floor of the room in which he died is changed.

In a Kiñah village the smithy is in a central situation. The Kiñahs smelt their own ore and manufacture their own iron ware. I watched the operation and procured a few samples of the metal. There is nothing peculiar to describe; there were an anvil, a couple of hammers, and a pair of twyers as usual, a charcoal furnace, a quantity of impure ore, and the usual primitive bellows. These people temper their own ore with a fragment of European ironware, when they can get it.

In front of a Lahanan village on the Rejang river there were four huge effigies, with the genital organs as usual fully developed; no indecency is intended, being merely relics of primitive worship [sic].

A fruit like an apple. called buoh rancleu by the Dyaks, is used to destroy vermin.

\section{Slaves.}

Outdoor slaves become so either by descent, by purchase, or by an amelioration of condition from having been indoor slaves. Indoor slaves become so by purchase or descent. In cases where both parents have been outdoor slaves the tabusan (purchase or freedom money) is 40 reals $(=\$ 28.80)$, or one picul of guns, unless the child is of tender years, when the tabusan is 80 catties $(=\$ 21 \cdot 60)$. In cases where one or both parents have been indoor slaves, but have become outdoor slaves at marriage, the children are outdoor slaves.

When one parent is an indoor slave and the other an outdoor slave, the children are divided between the owners of the parents, the first child following the condition of the father, supposing there be more than one child, e.g. : the father is indoor slave of $A$, and the mother is outdoor slave of $\mathrm{B}$; a child is borm and sex being immaterial to the question, it becomes half indoor slave of $A$ and half outdoor slave of B. The tabusan of an indoor slave having been fixed by the practice of the courts at 60 reals $(=\$ 43 \cdot 20)$, and that of an outdoor slave by descent at 40 reals, it will be clear that the tabusan on account of this first child to $A$ is in this case 30 reals, and to $B 20$ reals, should the parents decide on purchasing the freedom of their child, subject, however, if very young to reductions as above. But when two children are born, the first becomes indoor slave of $\mathrm{A}$ and the 
second outdoor slave of $\mathrm{B}$, the tabusan to $\mathrm{A}$ being 60 reals or $1 \frac{1}{2}$ piculs, and that to $\mathrm{B} 40$ reals or 1 picul.

Where the parent is free on one side, and the other parent either an in or outdoor slave, the first child follows the fortunes of the father, the second that of the mother, and so on in succession, and this rule is unalterable. For example, a claim was lately made upon a boy, whose father was an outdoor slave, and whose mother was a free woman. The boy was third of a family of five and both parents were dead. The owner of the late father claimed this the third child, but the friends of the boy said that before the father died he had declared that the second child should be slave, and that the third child should be free, the second child being also dead. The court decided that the father had no right to alter the succession, and decided in favour of the plaintiff. ${ }^{1}$ In cases where both parents are originally slaves, and after children are born one parent frees him or herself, the children born after the event, follow the above rule.

In cases where an indoor slave, man or woman, has become an outdoor one upon marriage, and has sought his or her own living, the children, so far as he or she is concerned become outdoor slaves, but he or she is still liable to pay his or her full tabusan to the master, no reduction being made unless the slave has become aged.

The owners of outdoor slaves have a right to demand the services of one child to work as indoor slave until marriage, when he or she quits the master's house and returns to his or her position as an outdoor slave; if a girl the master is on no account to receive barian (purchase-money) from the husband, and if a boy the master must provide barian, or at least assist in the matter for the reason that the boy has hitherto worked for his master and has had no opportunity of acquiring property for himself. The above rule is seldom enforced by the owners. The owner of an indoor slave, if the slave be a man, is expected to provide barian when the slave marries, and in such a case he becomes co-heir in the slave's property at death; if the slave be a woman, the owner receives the barian, and is still co-heir in case of death. In this case the husband generally prefers to pay the tabusan and to make his wife free. In no case whatever may an outdoor slave become an indoor one except in the case of a child for a time as above.

It having come to the notice of the courts that in certain cases masters exacted as much work from an outdoor slave as from an

1 Among the Punans the law seems a little different, the sex being of consequence; thus there was the case of a freeman who had married an indoor slave and a son and daughter were born. The son is free, following the condition of the father, the daughter is bond, following the condition of the mother. VOL. XXII. 
indoor slave, and that in other cases outdoor slaves could not be induced to do ariy work at all, a rule was made by which outdoor slaves became liable to be called twice a year to work for their masters, twelve days on each occasion, failing which they would be subject to a month's hard labour on the roads. No outdoor slave is to be called upon to work out of his river's district.

The property of slaves is now strictly protected, it having been found that masters sometimes helped themselves as a right to their slaves' property. In a case lately settled at Oya, a widow, indoor slave of a pangeran (high Malay official), possessed three sago plantations, and complained that her master had felled six trees, he having no land of his own. The pangeran pleaded that he only did what was customary; it was held, however, that he was wrong, and he was ordered to pay $\$ 9$ - the value of the trees and the costs of the suit.

The master of an indoor slave becomes as above-stated co-heir with the slave's other relations in case of death if he has provided barian; if not, his position on this point is as the master of an outdoor slave. The master of an outdoor slave may become co-heir only when the slave has no children. No master can refuse permission to his slave to free him or herself, or his or her children, whether indoor or outdoor, nor can he refuse permission to a slave to seek a new master, but he can complain to the courts if he has reason to think anyone has endeavoured to entice away his slave, and the person, if found guilty, would be heavily fined.

If a master seduces his slave she at once becomes free. There was a case in court where it was found that a master and his slave girl had lived as husband and wife for many years, and he had had children by her. The man died and his relations brought a case against the woman and her children to exclude them from the succession to the property of the deceased; but judgment was given in favour of the defendants on the ground that, though no marriage ceremony had ever been performed, the man and woman had been recognised by all their relations as husband and wife during the lifetime of the deceased.

The fine for bringing a slave into the country from foreign parts and selling him or her is $\$ 100$, and the slave is to become free. There was a case where a man brought a family slave into the country, whose tabusan was three piculs, and as no permission had been given to the man to bring him here the slave was allowed to seek another master who had to pay one picul only to the previous master. There was another case where a man was allowed to bring a family slave from Brunei, he having first asked permission, and the slave himself having been questioned 
by me at Brunei as to whether he liked to come here, and permission being obtained at the same time from the authorities at Brunei.

Where it can be proved that a master has not supported an indoor slave, nor called upon him or her to work for five years, the slave is entitled to become free. The court would, however, be very careful about giving judgment in the case of outdoor slaves, they being very nearly independent. On one occasion one family brought a case into court against another and very numerous family, to compel the latter to pay the tabusan and become free, as the latter positively would not work when called upon, the defence being that they were already free, having been P. Dipa's slaves, who had been declared free. After a long investigation into their antecedents and genealogy, the case was given against the defendants, it having been found that since $\mathrm{P}$. Dipa had left Maka none of the family had really worked for the plaintiffs, and that one of them had freed himself. An appeal was made to the then resident of the Third Division, but the previous judgment was confirmed, notwithstanding a letter from

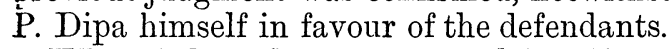

When indoor slaves contract debts, if such debts be trifling, amounting to only a few dollars, the masters are expected to pay; when the debt is considerable, should the master pay it, the amount is added to the tabusan, for which the slave is already responsible. Should the master be unable or unwiiling. to pay, the slave is assigned to work for him until the debt is paid off at the rate of $\$ 2.50$ a month. Slave debtors are unknown. When a freeman becomes hopelessly in debt, he is either imprisoned or assigned to his creditor to work off the debt as above, the creditor providing food and clothing; or the terms of his assignment may be that he sail in his creditor's pratu (boat) during the whole season- $\$ 7.00$ a voyage being allowed to and from Kuching, or $\$ 12.00$ a voyage to and from Singapore. During the close season the debtor must work in his creditor's house, and have such reductions made off his debt as may be agreed upon by the court. It has happened in a few cases that a relation has paid a man's deht and the man has been assigned to work for his relation until the debt is cleared off ; no monthly diminution being allowed, but even in this case the term slavedebtors has not been used.

In the old days, according to the old Dyak laws, people who were careless enough to set a house on fire rendered themselves liable to become slaves to those who had been burnt out and this may have gone on for two or three generatiuns, so that the grandchildren were slaves by birth. On one occasion the son of an old woman whilst smoke-drying some fish, fell asleep 
through weariness. The fire caught the thatch and spread rapidly through the long Dyak house, melting the people's guns and cracking jars. A neighbour told the woman what had occurred, and she. forgetful of the altered state of things, at once gathered her children and said to them "Death is better than slavery," paddled with them to the Dyak graveyard, where she ate and gave the children to eat tuba root, and only one child survived to tell the story.

Every transfer of slaves must be made before the court.

For treatment of captives, sie Warfare.

\section{Dress, Personal Ornament, and Fashionable Deformity.}

The ordinary male attire consists of a sirat or waistcloth, a labong or head-dress, and a takai buriet or seat mat; the full dress consists of the above with the addition of a klambi or jacket, and a dangdong or shawl.

The ornaments are grunjong, langgu, tinggu, kongkong, rekong, simpai, tumpa, tinchien, ngkrimok or unus.

The sirat, called chawat by the Malays, is a strip of cloth a yard wide, worn round the loins and in between the thighs so as to cover the pudenda and perinaeum; it is generally six yards or so in length, but the younger men of the present generation use as much as twelve or fourteen yards (sometimes even more), which they twist and coil with great precision round and round their body until the waist and stomach are fully enveloped in its folds. It requires considerable practice to enable one to dispose of so much cloth gracefully about the person, but more time is spent by these young dandies of the forest than one would imagine, in order that they may appear to the best advantage; and the Ulu Ais seem to excel all other tribes in the skill and taste which they display in the disposal of this personal attire. One end is so arranged as to fall over the coils in front and dangle between the legs; the other is hitched up behind so as to hang at the back like a long tail, or is looped up at the hip to droop on the right thigh. The former plan is adopted, where no takai buriet is worn so as to cover the hindquarters as much as possible. A practised eye can tell in a moment to what tribe or section of a tribe an individual belongs, not merely by the length of his waistcloth and the way in which it is wound on, but also by its colour and the fashion in which it is decorated at its extremities. White, as being the plainest and most unpretending, is worn in mourning and during outdoor labour; it is cheap and will wash. Dark blue, however, is the commonest throughout the country when out of mourning; it wears better, shows the dirt less, and is singularly becoming. 
Both kinds are sometimes bordered at the edges with scarlet flannel. Prints and shawl patterns are affected by the young men of the Ulu Ai and Ngkari tribe ; crimson, and saffron, and orange by the young of the Lamanaks and Sakarang tribes. A klapong sirat, or tail flap is often worn by the elder men of the latter tribes; it is of a dull white colour with a fringe to it, being made of home-grown cotton; it is prettily and fancifully embroidered with coloured thread and is sewn on to either end of the sirat to hang before and behind: The younger men and boys prefer the fringes, kabu sirat, manufactured by the Malays, or ornamental borders of coloured flannel.

The labong, or head-dress, is a piece of cloth a yard or two in length and wound round the head in the style of a turban, but so disposed that one end stands up straight from the forehead. But there are various ways of wearing, binding, coiling, \&c., whereby one tribe may be distinguished from another. A white labong is frequently the sign of mourning. Saffron and orange are favourite colours among the Lamanaks and Ngkaris; black prevails among the Saribas settled in Kajulan. The Ulu Ais affect shawl patterns and buntas, and the Sakarangs of Gutabai use Javanese handkerchiefs edged with scarlet and yellow.

By others, young as well as old, a kind of cap called selapok is much worn. It is made of plaited rush or cane, sometimes coloured and sometimes plain, as well as coarse or fine; and is shaped either to fit closely to the skull or to resemble an ordinary square cap. Fillets or head-bands of the same material and variable quality are also worn with an open crown and bordered with scarlet cloth. Helmets of wickerwork are in vogue on the warpath and will be noticed in their place.

The Kiñahs wear bark cloth round their caps (as we wear crape round our hats) to show they are in mourning.

The takai buriet is a small mat which is tied round the waist with strings so as to cover the hind quarters and furnish the wearer with a clean portable seat at all times, and at all seasons. The mat is of split cane and woven into an endless variety of patterns and decorated in a variety of ways, use being made of coloured flannel, nassar shells, and European pearl buttons for this purpose. Sometimes a bear's skin or a panther's skin is cut to the required size and worn in lieu of a cane one, and when this is set off with the requisite beadwork of the country it forms a most handsome ornament to the person.

The klambi, or jacket (baju, in Malay) is manufactured from yarn spun from their own cotton. There are several kinds of these, but the one known as the klambi burong is considered the best. In all of them the sleeves are open in the armpit, and the pieces sewn together with twine. The edges are bordered 
with scarlet cloth. There is another kind much worn by the Sakarangs which resembles a waistcoat more than a jacket, being without sleeves. The Ulu Ais manufacture a coarse white jacket striped with blue. The klambi subang manufactured by the Saribas is of finer and closer texture than any other, and is in consequence far more expensive. The thread of which it is wrought is procured from the Malays, and is of a red colour. The lower portion of the back is embroidered with gold and silver thread with a fringe of silk depending from it.

The dandong or shawl is worn slung over one shoulder.

The ornaments worn in the ear are various, some in the lobe and others, in the outer cartilage. The former are called langgu and the latter grunjong. The langgu of the Ulu Ai is borrowed from the Punan, and consists of a small but heavy coil of brass or copper. The Lamanaks wear larger but lighter ones of lead. Boys sometimes wear a narrow strip of scarlet as a pendant to the ear or a wing of the golden green chrysochroc (? buprestis) beetle, so highly valued in India.

The grunjong is worn in the rim of the ear, which is pierced along its entire length to receive the numerous rings of which it is composed, and it looks uncommonly pretty on the person; but when it is discontinued for a time as it often is from choice or by necessity, as in mourning for instance, and the holes are plugged with wooden pegs to keep them open, the cartilage looks hideously ugly and disfigured by slits. The rings are of brass, and smallest at the top gradually increasing in size until they reach the bottom. A very great many are worn in each ear by the young and vain, while elderly men are content with fewer. The variety worn by the Ulu Ai and Ngkari are strung with white cowries, which are kept in their place by a ruby bead at either end of the line, and are heavier by far than the plain brass grunjongs used by the Sakarangs.

The tinggu is a pendant worn at each ear to droop on to the shoulder and is only worn by over-dressed dandies. It is decidedly ornamental, being made of thin crescentshaped plates of brass stamped and fringed with metal.

A simpai lengan is an armlet, or as it is literally translated, a loop for the arm. It is worn above the elbow joint and is often of dark wood or carved ivory, but the kind most generally in use is formed from the base of the cone of the kima shell (conus guratensis), and is grooved on its upper surface. The cavity is filled up with resinous substance, and studded with the scarlet seed of the michelia or with a few nassar shells. It is a most becoming ornament but extremely expensive- 
a pair of the largest and best, costing $£ 6$. Occasionally two are worn on each arm, but this is considered bad taste and is discouraged.

The tumpa or bracelets worn alike by men and women are of three descriptions, and are called tumpa gelang, tumpa bala, and tumpa unus respectively. The first are of brass, the second of ivory and the last of plaited fibre. The two first consist of some sixty close-fitting rings commencing at the wrist and reaching half way up the arm; a few in the former are made to hang loose on the back of the hand and being engraved are styled tengkelai.

The tumpa bala or tumpa godieng as they are also called, have been adopted by the Sea Dyaks within the last few years from the Tetaks and Segans; they are now made in china and gold in Bornean Bazaars.

The tumpa unus are only worn by voung people too poor to afford any other kind ; they are merely rings of plaited gomuti palm fibre worn in heavy masses on the wrist.

Kongkong rekiong signifies "collar for the throat." Necklaces of European beads are worn by the young of both sexes; the ends are furnished with tassels of minute beads or bats' fangs. They are worn loose round the throat, and button in front, the tassels resting on the chest. Lamanak lads are fond of a large gold button as well as the tassel, but this is not universal even among their own tribe. Frequently several necklaces are worn, especially by the women. These necklaces of beads seem to have superseded the more savage necklaces of human teeth, etc., which were the fashion a generation ago, and is one proof of the civilising influence of the European government.

The tinchian tunjok are the rings worn on the fingers by both sexes. They are commonly made of brass, variously but rudely engraved, and are not soldered at the ends; other metals also are used but less frequently, such as copper, lead, tin. Gold and silver rings are procured from the Malays and used only by the tribes living in close proximity to them. Shell rings are less uncommon.

The ngkrimoks are hoops of cane worn immediately below the knee-joint, and covered with an infinity of diminutive brass rings. The hoops some eight or ten in number are strung together with coloured rattan to preserve a compact and regular appearance. The ngkrimoks are worn almost exclusively by tribes of Sakarang and Lamanak origin; the Ulu Ais and Ngkaris use the unus instead, and this consists of innumerable rings of plaited fibre worn in heavy masses, as many as 300 at a time upon each leg. The palm from which 
the fibre leg rings is made, is called apieng by the Dyaks and limak by the Kyans.

The female attire is very simple, consisting of a bidang or short petticoat when at home, and a klambi or jacket when out of doors. By way of ornament the women wear in addition to the finger rings, necklaces, and bracelets which have already been described, other ornaments peculiar to their sex, styled balong, tusok penchieng, tina, ranghi, lumiet or tinchien, selong and gelang ghirieng, all of which are described in due order.

The bidang is a short petticoat reaching from the waist to the knee, and is kept in its place by being folded over in front and tucked in on one side. It is manufactured from their own cotton fabric, which is first partially dyed and then worked into a variety of patterns to which the most fanciful names are given. The bidang worn in mourning is stained a deep indigo blue, and is called kain baloi. A lighter shade is worn out of mourning especially by the Ulu Ais, and is often adorned by them with small cowries or pearl buttons, and fringed with grunongs or little tinkling bells.

The klambi or jacket worn by the women is if anything larger than that worn by the men. The patterns are precisely the same but the texture is finer. The Saribas women wear besides a jacket dyed a ruddy brown with mangrove bark, with a square embroidery on the back, and a fringe of hawks' bells.

The balong is a chaplet of odoriferous berries worn by marriageable girls.

The tusok pendieng is a thin plate of embossed metal which is soldered to a small tube passing through a hole in the lobe of the ear; this tube is filled with a nut which screws into it, and keeps the tube from falling out.

The tina are slender hoops of crimsoned cane worn round the waist, and look like whalebone when coloured black, as they invariably are in mourning costume.

Rangki are the shell armlets already described under the name of simpxi lengan. They are only worn upon especial occasions, and form part of the full dress of a woman of fashion. As they are far smaller in size, and not so well finished, they are less costly than those worn by the men. Some eight or nine however are worn upon each arm, the more the better in their opinion.

The lumiet is the rawai of the Malohs (Malaus) and is a much esteemed body ornament of the Sakarangs. It is composed of a series of cane hoops covered with an infinity of diminutive brass links. A few of the hoops are made larger 
than the rest so as to hang loose on the hips. The series that encase the waist and the stomach fit close and are pinned together with brass wire; they are sometimes worn up to the nipples, but not every woman can afford to be at such great expense.

The tinchien is the body ornament of the Ulu Ai and Ngkari women. It is composed of some eight or ten parallel rows of large brass rings long enough to encircle the waist. They are strung on rattans and connected with one another by a network of cane inside. The ends of the band are furnished with a pair of vertical plates of the same metal, the outer edges of which are curled, the one inwardly, and the other outwardly, so as to catch one another, and effectively lock in the body. The rings (with the exception of every alternate one, which is an ordinary finger-ring), are long and broad, and rudely engraved a variety of patterns. These rings cost eight shillings a string, and a complete set of ten would cost five pounds.

The selong are dense coils of thick brass wire many fathoms in length, and of enormous weight, worn on the leg from the ankle joint to the thigh ; they are not worn every day, as may readily be conceived.

The gelang ghirieng bracelet is not described.

Love of finery is inherent in the young of both sexes; the elderly are less fond of it and often dress very shabbily and save up their good clothes for their offspring.

The women sit with their legs straight out in front, and their petticoats tucked in between their thighs so as to expose nothing, but they expose their breasts.

The Sakarang girls are very fond of using an oil made from the katioh fruit, which has the scent of almonds; all their clothes are made from native cloth of native yarn, spun from cotton grown in the country. The inner bark of a tree called ipoh by the Dyaks and tajam by the Kyans, and which appears to be identical with the Upas tree of Java (Antiaris toxicaria), is used for clothing, and the young tree is grown for this purpose in Dyak gardens ; the bark is not pulled off until a year after the tree has been felled.

Hair dressing.- The women make no attempt to part their hair but push it over the forehead and gather it into a knot at the back of the head-a plain or fancy one as the occasion may warrant. They use no oil of their own manufacture, but all who are able to afford the luxury may obtain it from the Malays. The hair is not so long as it might be, and is frequently cut short during dangerous illness. The circumstances of their lives are not favourable to a luxuriant growth. They have in common with the men their full share of exposure to 
all weathers, together with hard work out of doors as well as in doors. Flower's are worn in the hair as ornaments-red and green being the favourite colours.

The men dress their hair in a variety of ways. The genuine Ulu $\mathrm{Ai}$ fashion is to let the back hair grow long and flowing, and to keep the front either shaved or close cropped. The Ngkasi style is to shave in front and to keep the back hair close cropped, to shave again across the back of the head but to leave two parallel rows of hair and a tiny lock beneath them in the centre. The Kyan method of dressing the hair is, however, fast becoming the fashion among the dandies of all the tribes, e.g., to permit the back hair to flow to its full length over the shoulders and to grow the front hair over the forehead long enough to form a Grecian fringe. When it is inconvenient to have the back hair streaming over the shoulders, they twist it and tuck it carefully into the turban.

Depilation.-The prejudice in favour of a smooth face is so strong that in the whole course of my experience I have never met with a single bearded or moustached Sea-Dyak, although it cannot but be manifest to a close observer that were they only so disposed they could produce a thicker crop than the Malay. This is evident especially in the case of old men and chronic invalids who by reason of age or infirmity have ceased to care much about their personal appearance and whose chins are rough in consequence with a bristly growth. The universal absence of hair upon the face, on the chest, and under the armpits would lead the superficial observer to infer that this is owing entirely to a natural deficiency, whereas it is due in great measure to systematic depilation. Chunam, or quick lime, is frequently rubbed into the skin so as to destroy the vitality of the follicles The looking glass and tweezers are never out of the hands of the natives, and they devote every spare moment to the conscientious plucking out of stray hairs. It is likewise the fashion for both sexes to shave the eyebrows and pluck out the eyelashes. The growth upon the pubes in both sexes is often copious enough-some few Loweas object to even this, and either crop it close or remove it altogether. Female Dyaks cradicate the hair off the labia pudendla. I know a Malali at Kanowit who is bearded from ear to ear, and when he shaves, which is every now and then, his chin and cheeks are quite blue; he was a Mentuari of unmixed blood.

The Undups regard it as provocative of headache to throw their refuse hair into the fire or into the water. It may be cast on the ground or tossed to the winds; it is still better to bury it in the earth. 
Tatuing prevails to a small extent among the Sea-Dyaks, but it is by no means universal among them. It is besides a custom of very recent introduction but is steadily gaining ground, though as yet it is confined to the male sex. I have seen a few women with small patterns on their breasts, but they were exceptions to the rule and were not regarded with favour. The marks or patterns are found more commonly on the arms, shoulders, and thighs; occasionally also on the forehead, throat-apple, chest, and ulna. The patterns are small, of a bright blue tint, and supposed to improve the appearance of the men. They have no other use or signification whatever being neither distinctive of race, family, rank, nor of individual. The pigment employed is a solution of soot (dammar-soot), which is rubbed into the skin after it has been punctured. Tatuing has not yet acquired the dignity of a profession. Few Dyaks are really able to puncture with skill, although many of them can trace designs; but as their own designs are poor imperfect imitations of the Kyans, they disfigure the skin rather than adorn it. They say they are able to eradicate the pattern by puncturing it over again with the acrid sap of a forest tree. The designs employed are not numerous although four are in common use. The practice is simple but requires practice like most things. The design is first carved on wood in relievo; it is then smeared with the sooty preparation and printed on the skin. The figure is then punctured in outline with a set of needles dipped in the ink (for such it is), and afterwards filled up in detail. More ink is poured on to the skin and allowed to dry into it. Rice is smeared over the inflamed surface to keep it cool ; if this is not done, it is apt to gather and fester. The limb operated upon must be kept free from wet, and must not be scratched however much it may itch. The operator of course requires to be remunerated, but as he is not a professional he is satistied with a moderate guerdon.

Among the Lugats there was a certain Aman Jerin who was partially but beautifully tatued in patterns of a bright blue tint.

Painting.-The men never paint their bodies, but the women after bathing often colour themselves from the waist upwards with turmeric to render themselves yellow and attractive. The result is far from agreeable to the eye of an European, but for this they care little so long as their efforts to please are appreciated by the men of their own race, which appears to be the case.

Scars.-The men do not make any use of raised cicatrices to ornament the body, but they are proud of scars nevertheless 
and especially if they are regular and symmetrical. They are particularly proud of their vaccination marks if they show out well, and are equidistant apart. The women often prove the courage and endurance of the youngsters by placing a lighted ball of tinder on the arm, and letting it burn into the skin. The marks thus produced run along the forearm from the waist in a straight line, and are much valued by the young men as so many proofs of their power of endurance.

Ear-holes.--The rim of the ear is perforated from top to bottom with sometimes as many as twenty holes to support the ear-rings commonly used by the men. The lobe of the ear is also pierced and enlarged to receive a pendant. These organs present a hideous appearance when the ornaments are laid aside, as they reveal in all their deformity the slits and sores, while to add to their uncomeliness the holes are plugged with bits of wood to keep them open. These ear-rings, especially the heavy shell ones, oblige a man to lie flat on his back when he is going to sleep, it being painful to rest on the sides of the face.

Kyans and others wear tiger cat teeth in the tips of their ears. The points of Dians (a native on the Rejang river) I observed turned upwards, which is not usual, and he said it was an old custom revived by a chief named Hang. The Uma Lesongs wear two such teeth in each ear, the upper one pointing upwards, the lower one downwards; those who are unable to procure the genuine article wear imitation ones carved out of horn or bone.

Teeth filing and staining. - The upper incisors of both sexes are often filed into a single sharp point; a hole is bored through the centre of each and filled with brass. The enamel is scraped off with a rough stone, and the teeth are rubbed with leaves which stain them black. The lower incisors are ground down to half their natural size and blackened in the same fashion, but are neither pointed nor studded with metal. Caries is rare, and the natives seldom suffer from tooth-ache. The teeth are naturally beautifully white and regular, but it is the fashion to disfigure them in this manner as they approach the ages of puberty-boys do it when they begin to care to please the women. They dislike white teeth and consider them hideous. I once saw a Sakarang wearing over his natural teeth a thin brass plate (lios) cut to resemble a row of pointed teeth; this was worn over the upper incisors and hooked into the molars. I believe the boy picked up the notion from the Mentuaris or Malohs (Malaus), but I do not imagine it is common with his tribe as I never saw another with it either bèfore or after.

Circumcision. - Circumcision is practised but it is not 
universal or obligatory, and is only performed upon males. In the female the clitoris is said to be amputated.

The spritsail yard in the penis.-The palang is a smooth bar of bone or metal, the size and length of the bar of an ordinary watch-guard, with the ends rounded off. It is not generally so elaborate as the utang (perforation of penis) used by the Kyan chiefs, but it is equally effective and gratifying to the female. The palang is not, however, a Dyak institution; it originated with the Kyans, but it is fast becoming popular with at least a portion of the rising generation. It is nevertheless a pernicious practice, and ruinous to the male organ, even if the operation be skilfully performed; it is therefore to be hoped that the young fellows will discover their mistake before it is too late and refuse point blank to pander to the vitiated propensities of the looser behaved females. These latter encourage the practice for their own selfish purposes by every artifice in their power. The truth appears to be that no woman once habituated to its use will ever dream of permitting her bedfellow to discontinue the practice of wearing it. The Dyaks are satisfied with one, the Kyans, especially the chicfs, with sometimes as many as three at a time. The operation is a painful one for any man to submit to, and if the hole be not driven clear of the urethra the consequences are apt to be serious in the extreme. The member is first immersed in cold water and when numb to all sensation, the glans is compressed sideways between a pair of perforated bamboos, and a pointed brass peg is driven through it with a single blow, but in such a manner as to pass above the urinary canal. The palang is then introduced as the peg is slowly drawn out.

The palang unus, as it is called, is also used by the Dyaks. It is a ring, or collar, of plaited palm fibre, furnished with a pair of stiffish horns of the same wiry material. It is worn on the neck of the glans and fits tight to the skin so as not to slip off. The idea is in all probability borrowed from the Malays.

\section{Hunting.}

Hunting with dogs.-Hunting is with the Sea-Dyaks an occasional pursuit rather than a steady occupation or a necessity of existence. They subsist more upon a vegetable than an animal diet, and they fish far more than they hunt. They only form hunting parties once or twice a year, when the entire village is about to celebrate some periodical festival, and it becomes an imperative duty to provide an abundance as well as a variety of food for the guests. Other tribes devote more time to the chase 
and less to the soil. The hunter usually proceeds on foot, accompanied by his dogs, which run on ahead and beat up the game, while he dawdles about gathering things on the way that may be useful to him. He knows when his beaters are on the scent by their peculiar clamorous bark, and he hurries up to spear the animal they have brought to bay. A Dyak village swarms with dogs, but few of them are fit for the labours of the chase, being for the most part curs that whine and howl and are of no use whatever, except to consume the refuse food and prowl about the premises. They are small in size and of a tawny colour. The breed is known to the scientific world by the specific name of canis rutilans. Some are striped with black, others are plain; they are called scith or sabit, according as they are one or the other. The former are the fiercer looking of the two. The best of them, that is to say, those employed in the chase, are plucky little animals and will worry a boar three or four times their size and not give in until cruelly mauled. Such dogs are worth their weight in dollars to those who are fond of boar and venison, and invaluable to those tribes who, like the Batakans, depend upon the hunting path for their food.

The quarry is carried on the back in a pack-basket suspended from the shoulders, and is cut up at home. If it is too heavy or too bulky to be transported in this fashion it is either cut up on the spot or dragged by the leg along the ground to the nearest watercourse and conveyed home in a canoe. The Dyaks infinitely prefer pork to venison, the former being the richer, fatter, and juicier of the two; indeed the venison of the country is coarse and devoid of fat. There is no waste in the preparation of animal food. The horns and tusks come in for a variety of uses, ornamental, superstitious, and economical. The larger bones are preserved to be hereafter fashioned into knife handles. The smaller bones are chopped up with the meat and fat to be afterwards salted or smoked as choice may dictate. All pickled food, makasam, is esteemed, and especially so pickled pork ; pickled venison and pickled fish are devoured with immense satisfaction.

The Kiñahs preserve the skulls and jaws of the animals killed by their dogs in the chase, and of such as they offer in sacrifice; but they abandon them when they abandon the village, for it is not permitted by custom to take them away from one place to another.

Spring bows.-As the woods are full cf pig and deer, the Dyaks resort to various contrivances to secure these denizens of the forest. Spring bows are set and pitfalls are dug in likely places for them to run against and tumble into. The peti, as 
the spring bow is called, consists of a single bamboo lance attached to an elastic stem. This lance is laid in a horizontal direction above the ground about the height of the animal it is intended to transfix. A sapling bent for the purpose forms the spring by being held back; a string crosses the path, the least touch of which loosens the spring and forces the bamboo in a straight line across the path and consequently through the animal that may happen to be passing.

The nklubang, or pitfall, is another common contrivance to impale game. The bottom of the pit is staked with bamboo or iron-wood spikes, and the opening is covered with twigs and leaves so as to be in no way distinguishable from the surrounding vegetation.

Deer snaring.-The jarieng is also in use among the Dyaks, the idea being borrowed from their neighbours the Malays. The object is to drive the deer into the meshes of a net and to kill them before they can break through. This sport requires nerve and a quick eye to avoid ugly wounds from the hoofs and antlers. The jaricng, as this net is called, is simply a long cano cable with a continuous series of cane loops or nooses depending from it, and standing five feet high; if a single cable be insufficient, two or more are joined together until the required length is attained. A bend of the river is selected where the deer are known to lie hid. The net is then stretched across the narrow neck of land, and upheld in an upright position so as to intercept the stampede into the bush. The party then divides, some to watch the net, others to drive the deer towards it. This they do simultaneously from both sides of the point, yelling and shouting with all their might and barking like dogs to rouse the game. The startled deer spring from their coverts, and bounding towards the forest encounter the net and get entangled in its meshes. Before they have time to extricate themselves they are despatched by the watchers. This sport can be followed in the night time as well as in the day time provided there be moonlight.

Springes.-The smaller kind of game such as porcupine, pheasant, partridge, jungle fowl, \&c., are caught in springes, and by, these alone a clever woodman can supply daily his family with this kind of food in abundance. The cord made use of for their springes is of their own manufacture, very fine and strong, and made from the inner bark of several kinds of trees. They have also cage traps, into which the squirrel and mouse deer are attracted by choice food, and which fall upon and detain them. Pigeons and other birds are caught with springes and bird lime placed in the trees which they frequent for food, particularly the different species of Kasu ara (ficus) 
which are very abundant and on which the many species of these birds delight to feed.

The sumpitan.-Great accuracy is shown in the way in which this tube is drilled out of a hardwood shaft some seven or eight feet long. Among the Punans it is common to destroy wild boar, deer, \&c., with the darts.

Pig sticking.-Once a year, when the falling fruit is thickening upon the ground and the pigs have cleaned out one side of the river, they instinctively take to the water and endeavour to reach the opposite bank. The natives know when to expect this wholesale movement on their part, and as the time draws near they form parties to waylay the pigs at various points. They wait patiently for days together, and are rewarded ultimately by spying a herd issue from the forest and plunge into the stream, following their leader in a dense compact mass. When they are well in the current the canoes dash into their midst, sticking them right and left, making enormous bags. As the swine have been feeding upon fruit for some time past they are fatter than usual and their meat is better flavoured.

Crocodile hunting.-From superstitious motives the Dyaks do not interfere with the crocodile until it has developed a man-eating propensity. They then turn out in a body and make war upon the race and slaughter it wholesale. They take the heads and hang them up over the fireplace side by side with the cluster of human heads which depends from the roof. When the Dyaks of Pulo Pisang lost one of their number a few years ago they made a war path and killed sixteen crocodiles in revenge, and when Avan Nyipa, of Batu Gadiang, lost his wife, the Kyans and Sebops turned out en masse and destroyed thirty within a month. They probe the bottoms of the pools and other likely places with long poles and compel them to rise to the surface and despatch them with their spears. The Undups believe, or affect to believe, that the crocodiles are partial to their tribe, and they are therefore reluctant to slay them. They say that once upon a time when the king of the crocodiles fell ill and was sick unto death an Undup medicine man was fetched to cure him, and received as his reward a distinct promise of immunity from ravage for himself and his tribe for evermore, notwithstanding which, however, an Undup woman was afterwards seized, but the monster let her go when she screamed out. She was rescued by her friends, who declared that the brute mistook her at first for a Sakarang, but let her go when her voice proclaimed her to be an Undup.

The ordinary way to take a crocodile is with a baited wooden hook and slack cable. The most irresistible bait is the carcase of a dead monkey (dog or fowl will do), and the more over- 
powering the stench the greater is the probability of a bite, as the brute will only swallow putrefying flesh. Fresh meat is carried away between the jaws and hidden in some safe place until it decomposes. The line is a loose one of rattan, many yards in length, and is not made fast, so that the reptile may drag it away with him when he bolts the bait. The buoy at the other end of the line floats on the water and serves as a clue to his whereabouts; and when he is discovered he is hauled ashore and pinioned. While this is being done he is addressed in eulogistic language and beguiled, so to speak, into offering no resistance ; but the moment his arms and legs are bound across his back and he is powerless for evil, they howl at him and deride him for his credulity. They then rip up his belly for human remains and hew him to pieces. He struggles furiously at this stage but to no purpose, and is speedily decapitated with an axe. A short stick pointed at both ends is often used instead of a hook, and is secured to the bait in such a fashion that it is swallowed lengthwise. To ensure this result the bait is hung upon a bough overhanging the river, but several feet above the level of the water to oblige the crocodile to spring upwards in order to reach it. The efforts he makes to disgorge the wood work it round so as to stick in his throat crosswise. It is usual to hang a dog higher up in the same tree so that he may attract the cruising reptile by his unhallowed howling.

The Sarawak crocodiles vary in length from ten to twentysix feet, but the common size is from ten to fifteen feet. They become a public nuisance from the date of their first human meal, and are thereupon hunted to death. Manang Blitang, of Yong, is perhaps the most successful and persistent crocodile trapper in the Rajang River. $\mathrm{He}$ is supposed to possess supernatural power over them, and his services are therefore always in request where a seizure has occurred, and the kinsfolk are anxious to discover the whereabouts of the guilty reptile.

The porcupines and monkeys are hunted for their bezoar stones, ${ }^{1}$ the squirrels for their fur and their teeth (squirrels' teeth are used for necklace tassels) ; bears and tiger-cats and panthers are hunted for their canine teeth, their skins being used for warjackets and seat mats; the hornbills, jungle fowl, and argus pheasants for their plumes for decorating helmets and sword sheaths; the bill of the rhinoceros hornbill is wanted for ear pendants and helmet crests, and crocodile teeth are wanted for ointment cases; bears' teeth and boars' tusks are wanted for charms, and the crimson horn of the buceros rhinoceros is used

1 Calculi forme $l$ in thei" stomachs, much valued as amulets. VOL. XXII. 
for ear pendants ; the helmet of the galeatus is used for a swordbuckle.

\section{Fishing.}

The Dyaks are expert anglers, and fishing is with them a favourite occupation. They commence fishing at a very early age, and the habit grows upon them rather than otherwise. They are fond of the water and both swim and dive well. They swim hand over hand like dogs. They never take a header in diving but jump into the water upright, sinking feet first.

Diving for Fish.-They often catch the fish in the upper waters by diving into the rocky pools and pulling them out of the holes and crevices. The sema especially are caught in this way.

Curing.-The women cure the fish. They either dry it in the smoke of a wood fire, or cut it up and boil it in brine and so preserve and pickle it, making makasam ikan.

Scoop net.-The scoop net is used chiefly by the women who are fond of wading up the shallows, net in hand and basket suitong, slung from the shoulder, scooping up the prawns and periwinkles, \&c., that come in their way. Sometimes they drop the fish into a hollow gourd which they carry.

Casting net.-The jala or casting net in ordinary use is made of tengang string dyed claret colour, with samak to preserve it, and is weighted with stones if nothing better is to be obtained.

Angling.-They fully understand the use of a bait and invariably bait their hooks. Fish lines are made of the apieng palm.

The Fish-spears in use are the penawan and serampany; the penawan is simply a barbed spear with a slender iron fore-shaft; the serampang is a forked spear furnished with a long bamboo shaft, and with either two or three metal prongs.

The Fish-traps in every-day use are the bubu and abau. They are both of stiff basket work and resemble an acorn in shape; the only difference between them is that of size; the latter being infinitely the larger. The traps are made of the ribs of the apieng palm.

Fishing by torchlight.-Another mode of fishing is to creep along the bank in a canoe after dark with a torch in one hand and a fish spear in the other, to stick the mudfish as they rise to the surface confused by the light. Prawns are also caught in this fashion but with a hand net. 
Tubai fishing.-But the favourite form of fishing whether on a large or on a small scale is with the tubai root (menispernum) the juice of which is baled into the stream to poison its waters and to cause the fish to rise stupefied to the surface. The empang, or basket work screens, are first erected at the mouth of the river to prevent the escape of the fish into pure water. Each person brings his own tubai-a bundle or two. A karangan is selected where suitable stones abound. It must be two or three hours' pull from the entrance or the sport would be over too soon. The canoes line either bank, and at a given signal the entire bala, i.e., party, commence to hammer out the root and soak it in the water in the bottom of their boats. A few minutes later when all hands are ready the poisoned liquid is baled out into the stream, and the canoes after a short pause begin to drift slowly down the current, and as the fish rise to the surface, they are speared with fish-fork or captured with hand-nets. The best of the fun is over in an hour or two, but many remain, nevertheless, until late in the evening to watch for a fresh rise. The women join in the sport and scoop up the small fry with their nets. It is forbidden by custom to hurl the spear at the fish; any accident arising from an infraction of this rule is punishable by fine.

\section{Navigation.}

The canoes are hollowed out of a single log by means of fire and the use of the adze. The natives have no measure to ensure accuracy, but are entirely guided by the eye. Generally the canoe shows traces of the fire and water treatment it has received, the inner surface being soft and full of superficial cracks, while the outer surface is hard and close. When the shell has been sufficiently opened out, thwarts are inserted to prevent its shrinking as the wood dries. Planks or gunwales are stitched on to the sides to increase its volume, the seams being caulked with sago stems which are light and porous, and swell when wet and so keep out the water. Each of these side pieces is formed of an entire plank about 12 inches deep and about $1 \frac{1}{2}$ inches thick, laced on to the body of the canoe by flaxen cords and united to its opposite plank by the thwarts. The largest canoes have the sides made still higher by means of a narrow plank laced on to the first gunwale, and the sedm again caulked. The canoe is alike at both ends, the stem and stern being both pointed, curved, and rising out of the water. There is no keel, and the canoe draws little water. There are no ribs nor is there any figure head.

To make a bark canoe the native simply goes to the nearest s 2 
stringy bark tree, chops a circle round it at its base, and another circle 7 or 8 feet from the ground; he then makes a longitudinal cut on each side, and strips off as much bark as is required. The ends are sewn up carefully and daubed up with clay, the sides being kept in position by cross-pieces. The steering is performed with one or two greatly developed fixed paddles.

\section{Weapons and War-dress.}

The sligh $i$ is a wooden lance, the point of which is hardened in the fire. It is used as a missile and is hurled at the enemy. It is usually of ironwood (bilian), but palmwood javelin, especially inbery is also used. They are showered upon the enemy at the commencement of an engagement before the parties are close enough to use the spear, which never, or rarely leaves the hand.

Dart stems are made of the palm called apieng. The poisonous juice of tasam tree is used for their darts; it is dried over the fire until it becomes a hard paste, and is then softened with the juice of an akar, creeper.

The sangkoh is a long wooden shaft with a steel spear head. The shaft is usually of ironwood, with a spud of bone at its buttend. If it has nospud it is pointed so that itcan bestuck into the ground. It is always held towards the point, rather than by the centre, and over the right shoulder, the butt end up in the air, and the point towards the ground. The blade is of steel, and is 12 inches in length, and broad towards the point; the tang is not inserted in a slit in the wood, but is bound on to the stern with cane or brass wire, and is very firm. The spear is used at close quarters to thrust with, and is held in the right hand-the shield occupying the left. The shaft is occasionally carved, but more often plain. I have one in my collection with six or seven brass rings, indicating the number of warpaths made by its owner.

The dukn, or parang pedang, is the scimitar so much worn by the Malays, and differs only from it in being thicker and heavier. It is formed after the pattern of a German cavalry sabre, and has a cross-handle of brass. The blade is two-edged at the point, so that it can be used for thrusting as well as cutting. The sheath is of some light wood, and is stained crimson with dragon's blood. The Undeys and Balaus in particular have their sheaths covered with silver work, and the hilt with silver. The hollow of the hilt is decorated with human hair, and the edge of the sheath is adorned with a row of the wing feathers of the hornbill. The Malays wear the sword with the edge upwards but the Dyaks wear it with the edge outwards. 
The parang ñabur seems to be the only really genuine Dyak weapon. The parang pedang they have copied from the Malays, and the parang ilang is altogether a Kyan weapon, and beyond their powers of imitation. The nabur in ordinary use is a short.curved sword with a bone handle. This style of sword is broadest at its points of curvature. It does not curve like a scimitar from the hilt, but is straight for some distance, and takes a sudden curve towards the end, and when the sword is long, as is one in my collection, it becomes top heavy and requires both hands to wield it effectually.

The parang ilang is the Kyan malab (mandau elsewhere), and is preferred to any other side arm by Malays as well as Dyaks. It is the ambition of every Dyak lad to be presented with one of these.

The Uma Bawangs are famous for their parangs, which they make out of their own iron ore.

The war costume consists of a basket-work hat called a katapu and a skin-jacket called a gagong; in lieu of the latter the klambi taiah (?) a quilted jacket is used. These form but poor defensive armour for the body; reliance is placed upon the shield.

The katapu or helmet in general use is a round skull cap of wicker work, with a rush lining and occasionally a skin covering, surmounted by either a metal plate or two of fanciful pattern or the scaly armour of the tenggolieng. The crown is decorated with the plumage of kirds and the sides with tufts of human hair. The rim is bordered with scarlet flannel and embroidered with nassur shells.

The Kyans and Kiñahs wear on their headpieces the tail plumes of the helmeted hornbill-each plume signifying a dead enemy.

The gagong or war-jacket is a skin with a hole and slit in the neck of it to admit of the insertion of the warrior's head, the animal's face falling on his stomach, and its back hanging over his shoulders and reaching below the waist. This dress is by no means universal among the Dyaks, as suitable skins are not, so easy to obtain. Goat skins are preferred by them to any other, being long haired at the shoulder, and black is preferred to white; bear skins and panther skins are also in use but more sparingly. The animal's face is usually covered with a metal plate, or a mother-of-pearl shell, to protect the pit of the stomach, and the back is decorated with bunches of hornbill feathers. The gagong is worn more for its warlike appearance than for any real protection it affords the wearer. It may possibly divert a wooden javelin, but it is no defence against the thrust of a spear. The Kiñahs wear the mandibles of the 
Bucerotidae (hornbills) in pairs on the breast of their warjackets of skin to record the number of persons they have killed with their own hands-one pair for each person killed.

The klambi taiah is the boju tilam of the Malays, and is a padded or quilted cotton jacket, for the most part sleeveless and collarless. The striped variety is the one most in request. It is thick enough to be able to protect the body from the blow of a wooden javelin, but is useless against a spear.

The trabaiklit klau, or shield, is with its handle hollowed out of a single block of wood. Its form is oblong and convex with a ridge along its centre. It is held in the left hand well advanced before the body, and is not meant to receive the spear point but to divert the spear by a twist of the hand. It is often coloured with red ochre or painted some elaborate design or fantastic pattern. It is large enough for its purpose, but it is small compared with the shields manufactured by the Sibus and others. There are also seen in use among them wicker-work shields of plaited bamboo, corresponding to the wooden ones in length and size.

\section{Aggressive Warfare.}

Dyak warfare is far from despicable, although it is undisciplined, and when the command is assumed by a person of sufficient influence to enforce obedience, the force at his disposal becomes more formidable than it otherwise would be; but this is not so often the case now as it used formerly to be. In fighting, the warriors cluster round their chiefs and are indifferent to the fate of the others so long as the chiefs escape with life and limb. Similarly relatives cluster together, preferring to entrust their lives to the tender mercies of one another, rather than to a stranger; a relative would bestride his fallen kinsman and protect his body from mutilation, when a stranger might decline the combat and leave him to his fate. They carry away the dead and wounded when possible; the former they bury, but, if hurried, often so imperfectly that the enemy scent them out, dig them up and carry away the heads. When unable to carry away the dead, they have sometimes severed the head from the trunk and carried it away with them to bury in the forest, rather than let the treasure fall into the hands of the enemy.

It is customary to announce a coming war expedition for such and such a season at one of the great feasts, when the village is thronged with guests from the country far and near, and when there is sure to be an unusual gathering of powerful chiefs. The speaker, who must be a great chief, gives his reason, that 
his people wish to put off mourning, or that his people have been slain and he must have some revenge, and he ends by inviting all present to accompany him on an incursion upon an ancient enemy. If he be a chief of any real influence he is sure to secure an ample following, in reality more than enough for his purposes, but his ambition expands as his numbers increase and his warpath assumes grander proportions. The women lend their assistance to induce their husbands and lovers to join the warpath. Before this, however, the chief whose mind is set on the business gets together a circle of chiefs and warriors, which before the end of the proceedings resolves itself into a council of war. The expediency of the campaign and the exigences which demand it are then openly debated, and if the majority or even a strong party are in favour of it, the chief who originally broached the topic, if he feels confident of a following large enough to effect his purpose, announces his intention of becoming a leader and the date of the departure for the enemy's country. All present are invited to accompany him and to bring their friends and relations. The details are then discussed, the amount of bekals (baskets) necessary, the route, the character and number of enemy, etc. The period usually selected for any expedition on a large scale is that immediately after the seed planting or after the harvest; the former time is preferred when available as they can spare the time better, and have three months clear before they are required to gather in the harvest. In the latter case they would probably have no farms at all for that year, as they would have no dry weather to dry the clearings, which, therefore, would not burn well.

As the time draws near for the expedition to start, a spear is sent round the country from village to village with a tembubu toli, to signify how inany days are to elapse before the commander-in-chief is able to make a start; a place is also mentioned where he will await the force. The women are everywhere busy preparing the bekals, and the produce of the gardens are taken to the nearest market to exchange for tobacco, chunan, gambir, etc. The men on their part have been busy in getting the war boats ready, launching them into the river, lashing on the planks and fitting them up with palm leaf awnings and bamboo floorings. Those who are able to purchase the material, plane the bottom of their canoes to make them smooth and tar them to preserve them, make figure heads for the bows, and paint the side planks in various patterns. They take nets with them to fish by the way, and dogs to hunt with if the distance is so great that they are likely to run short of food, but their chief support on an expedition of this kind is what they find on the banks and in the forest-especially the 
wild sago. The men are very busy furbishing up their arms and sharpening their weapons and decorating their helmets and war-jackets. [As long as the men are away their fires are lighted on the stones or small fireplaces just as if they were at home. The mats are spread and the fires kept up till late in the evening and lighted again before dawn, so that the men may not be cold. The roofing of the house is opened before dawn, so that the men may not lie too long and so fall into the hands of the enemy.]

The chief is always the first to leave the village, and as the first and chief part of the journey is by water, he pulls away in his canoe, and at some convenient distance from the village, he bivouacs for the night to beburong -to consult the omen birds. If the omens by birds are favourable, he proceeds to the tryst and there awaits the force as it dribbles in one by one or few by few. When all or most have arrived the flotilla moves on uncontrolled until it reaches the pengkalan or landing-place, whence the overland route commences. There is no attempt at order or regulation as long as they are in the water and in their own country, every boat stopping and moving much as it pleases, but all trying, nevertheless, to reach the pengkalan at once. If this is close by there is a dash for it, but if it is several days' journey there is a good deal of loitering by the way to increase their stock of provisions or to equip themselves more fully with kejangs (deer), poles, tukahs (pegs), etc. and cords for hauling rapids. The chief brings his musical instruments with him and plays on his gongs and lawahs as he sweeps along. The line of march is most irregular, the canoes not moving up in a line but with wide gaps, some outstripping each other, others lagging behind to cook and angle, others deterred by bad omens and adverse dreams obliged to halt for the day, others to dry their things capsized in the rapids, etc.

It is a grand sight to see these canoes filled with dusky warriors whose naked arms and bodies are just visible beneath the awning, pulling away with a uniform and vigorous stroke, uach arm with its white shell bracelet, and the chief standing up in the stern steering the rudder with hand and foot. The canoes hold each from twenty to seventy men.

Arrived at the landing-place, a camp ${ }^{1}$ is formed, but the huts are not arranged in any military fashion, but line the banks of the river. The langkan, or hut, is built sometimes to accom-

1 Kyans, when they make their camp, strew dead leaves outside the fence so that no one, not even a dog, can approach without being heard. Punans make their camp in a circle, each hut facing a different direction, so as to prerent a surprise. 
modate a whole boat's crew; the warriors lie side by side, their spears are stuck in front, and their shields and swords in their hands, so that they can spring to their feet, arms in their hands, in the twinkling of an eye. The roof slants upwards from the ground and forms an angle with it. It is thatched with leaves and branches; the flooring is of the same material with a layer of bamboo or sticks. A fire is lit hard by to keep off the mosquitoes and sandflies, who are often troublesome. These huts are meant to last a single night, or several, according to the care with which they have been built; but stronger huts are reared when a stay is expected to exceed a few days. Here a halt is made of several days' duration to explore the neighbourhood, and to permit stragglers to come up. The canoes are hauled up and concealed in the forest, and the track examined. A war-council is held, and the route marked, and the situation of the enemy discussed, and on a given day the march commences, each one shouldering his pack and stepping out in Indian file-the guides ahead, and closely followed by a few of the hardiest, boldest, and most experienced men at their heels. This line of march reaches many a mile if the war party be a numerous one. The pace is rapid so long as they are in neutral territory, but slackens as soon as they reach the borders of the enemy's country. The leaders then proceed more warily as the enemy, if forewarned of their approach, are pretty sure to be posted in ambush by the way.

As Dyak warfare consists of surprises, they do not attack a village, or a cluster of villages, if their approach has been discovered and the population is on the defensive, but they content themselves with cutting off stragglers, and lie in ambush at the waterside for people going to bathe or to examine their fish traps, and in the forest for individuals out hunting or produce collecting. But if their approach be unknown, they so manage as to reach the settlement before daybreak; generally they draw a cordon round it at midnight, and tighten the circle before daybreak. If the ladders are down they rush up to the house and take it by storm; if they are drawn up they hurl lighted javelins into the thatch and fire it. They never spare the men, and rarely the women. Heads are more valuable than captives, but they do sometimes make the women and children prisoners, and reduce them to slavery.

When argued with about their head-hunting expeditions, the Dyaks plead ancestral custom: "It is the custom of the white man to read books, it is the custom of the Malays to say their prayers, but it is our custom from ages to go on the warpath." 


\section{Defensive Warfare.}

If the Dyaks have reason to apprehend an attack upon their village, they put it immediately into a state of defence, i.e., they raise a tall palisade around it and encircle this again with a wattle fence and chercuux de frise of spiked bamboos. The waterside, the landing-places, and the approaches to the village, are all spiked, and also the foot of the ladder, and they dig pitfalls in the pathway. Their valuables they conceal in the adjoining forest, or in the vicinity of their farms. The moment the enemy appears the sound of the tawah begs to announce their condition to their neighbours, and to summon them to their assistance. If they are heard help is sure to arrive instanter. If they feel confident of their ability to repel the enemy, they keep their women at home; but if there is any doubt about the matter, they conceal them with their treasures on the hills and flee into the forest to rejoin them at a rendezvous when resistance becomes hopeless. If they are in no hurry they fire the village before they leave it; if on the other hand they wish to gain time, and to divert the pursuit, they leave it for the enemy to plunder and burn.

A favourite stratagem is to entice the leading boats of the enemy into an ambush on shore. As everybody is anxious to be foremost in the race for heads, there are sure to be one or two boats so far in advance of the rest as to make it worth while to put them to their mettle. Some convenient spot is selected and a strong party placed in ambush among the trees. One or two men are thrown out to stroll upon the shingly bed to lure the enemy to their destruction. The moment they are caught sight of, the boats give chase, and as the warriors leap ashore, the men in ambush spring from their covert to their feet and hurl stones to shatter the shields, and engage with spears and swords in a short but desperate conflict. As the main body is seen winding up the river, whooping and yelling, and crashing up in clouds of spray and with a rush of waters, they plunge into the thicket with the heads they have obtained, and are far away before the enemy have recovered from their discomfiture, and are prepared to follow.

Another stratagem is one of ambush. When the head of the column is close upon them (the ambush), they discharge their muskets, leap from their ambuscade, and engage in a hand to hand combat. The Dyaks always waylay on the right-hand side of the line of march, as that side of the body is unprotected by the shield, which is carried in the left hand. A short, but desperate fight ensues, a few heads are taken, and the enemy scampers off with their dead and wounded 
before the main body can come up. The invaders pause a while until reinforced, and then pursue, but the enemy have taken advantage of this delay to plant tukahs in the path and ranjans in the water-way. Some are sure to get spiked, and another delay ensues. The ambuscade is by that time beyond pursuit. If the enemy are plucky, they form several ambuscades, and so impede the progress of the bala (war-party).

When acting on the defensive, if it is intended to entrap an enemy by water, it is customary for the entire force to divide into two equal portions, and to be hid in two branches of the main stream, and sufficient distance apart, and when the enemy are in between, to dash out sinultaneously and take them in front and rear. If the invading force is too numerous to try this, is to lure the leading boats by a decoy boat into a position where by reason of the rapidity of the current and obstacles in the river they can be taken at a disadvantage, and to scamper off with a few heads after a desperate and hurried fight before the main body comes up.

It is a defensive measure to blockade the passage up the river with huge trunks of trees felled right across, which form a temporary barrier to quick progress; stakes and tukam (?) are placed in all suitable places, and in the shallow beds to impale the feet, as the men have to tumble out of the canoe to haul it over the rapids, \&c.

\subsection{Heads.}

The way of cutting off the head varies with the different tribes. They do not always cut it off the same way. - The Dyaks and Bekatans have each a different way, and by the manner of it it is known whether it is a pumjong iban or a pumjong Bekatan. The Dyaks sever the head at the neck, and so preserve both jaws; they scoop out the brains through the nostrils and hang it up to dry in the smoke of a wood fire-the fire, in all probability, at which they are cooking their victalals. Sometimes they tear off a bit of the cheek skin and eat it as a charm to make them fearless. They cut off the hair to ornament their sword-hilts and sheaths, \&c. If the jaws drop they fasten them up, and if the real teeth fall out, or if they extract them, they fill up the cavity with imitation ones of wood. They put studs in the eye sockets, but do not carve the skull, as do the Kyans. They generally plug the nostrils with wooden stoppers. Everything is done to propitiate the head; food is put into its mouth, betel nut is prepared for it, and even a cigarette ; it is implored to remain among them, and to induce 
more of its friends to come that way and keep it company. They cut out the tongue.

The head does not in. an expedition belong to the person who takes it. It belongs to the chief, and if there are several it is distributed among the leading chiefs. If only one head is obtained, and there are many claimants to the honour of salaiing it, it is broken into pieces, and a fragment given to each; but this is not popular with the Dyaks, and it is more usual for the most powerful chief to keep it. But the chief who salais a head undertakes a great responsibility, as he by that act aspires to be a war chief, and must lead the people on the warpath. They look up to him, \&c. They do not mind his keeping the head as long as he gives them an opportunity of cutting off others. When brought home the head is hung up in the verandah of the house outside the chief's apartments along with the smoke-blackened cluster of heads depending from the sloping roof and overhanging the fireplace.

The Uru Ais believe that the persons whose heads they take will become their slaves in the next world.

\section{Captives.}

The Dyaks too often spare neither man nor woman nor child, but sometimes, when more humanely inclined, or when the opportunity offer, they carry the women and children away with them into captivity. But it is a remarkable fact that there are so few slaves, or persons of servile descent among the Dyaks. Other tribes keep their slaves in a condition of perpetual servitude, but the Dyaks allow their friends to ransom them, and if they still remain on their hands they adopt them into the tribe and enfranchise them. The ceremony is usually performed at a great feast, the owner announcing that he has freed so and so and adopted him as a brother, and he is presented by the chief with a spear, with which he is told to slay the man who dares hereafter call him a slave. They are not cruel to their captives, but humane. The one solitary instance in my experience of cruelty to a captive, is the one related by Rajah Brooke in his work.

\section{Cannibalism.}

[The following letter appears to have been sent to a Sarawak new spaper.]

"SiR,-I have just been reading a second time in 'Headhunters of Borneo,' and in connection with it, Mr. Bampfyldes' remarks, together with Mr. Bock's rejoinder. I have been 
asked by the former gentleman to testify to his credibility, and shall therefore feel obliged if you will be good enough to insert these few lines for the information of the public.

"I have been 400 miles up the Rejang River since the publication of the above volume, and though I had not yet read the book, I took it with me and showed the plates to the natives of the interior; so true were they to life that resemblances were found in the portraiture to their own friends, and every detail provoked roars of laughter.

"Mr. Bampfylde has, however, been over six years in Rajah Brooke's service, therefore his testimony, I feel sure, is preferable to that of a mere traveller.

"I fully believe, with Mr. Bampfylde, that the natives were poking fun at Mr. Bock when they declared the Trings to be cannibals. I do not believe them to be such, for if they were I should have heard of their propensity long before Mr. Bock ever set his foot in Borneo, for we have occasional intercourse with some of the tribes of the Upper Mahakan, among whom Mr. Bock should have travelled instead of stopping short at M. Pehau, which can be reached from the sea by steamers, and which feels the influence of the spring tides. Had he accomplished the ascent from this point upwards, he would have endangered his neck it is true, but he would have travelled over new ground, and added to our knowledge. A few months ago I received a visit from a Long Gelat, named Bau Dias, who lives at the foot of the Mokan ranges, and I put the question relative to the alleged cannibalism of his neighbours, the Trings. He seemed surprised at my asking such a question, and said ' Of course it is not true, such a practice is unkuown to us at Mokan.'

"I do not accuse Mr. Bock of wilfully publishing an untruth, but I fully believe his credulity was practised upon by his companions to discourage in him any desire to penetrate further into the interior.

"I do not think Mr. Bock will require to return any answer. to what I have written. I, for my part, do not wish to engąs in any controversy, and disclaim any obligation to make further reply.

"I have the honour to be, Sir, "Your most obedient servant, "(Signed) Brooke Low.

"SARAWAK, "20th September, 1887." 


\section{Musical Instruments and Singing.}

Rudieng.-The European Jew's harp is a small musical instrument held between the teeth, and having a metal tongue, which, when struck by the finger, produces musical sounds that are modulated by the breath. In the Dyak rudieng, the little finger of the left hand stretches the string loop at the left end, and the thumb and first finger hold the metal handle; the cross-piece is held between the thumb and finger, and pulls the concave inside. It is used by a young man to talk to his young girl at night, when they do not wish the mother to overhear their talk-they are able to understand each other in the language of love. The length is $3 \frac{3}{4}$ to $4 \frac{3}{4}$ inches; the narrow end is $\frac{1}{16}$ to $\frac{1}{4}$ of an inch wide, and the broad end $\frac{3}{8}$ to $\frac{1}{16}$ of an inch wide. It is a perfectly intelligible wind instrument; a metal plate of unequal width, narrowest where it is held in the left hand, and widest where it is held in the right hand. The string is jerked by the tongue, which is likewise metal, vibrates and resounds in the cavity of the mouth. The sounds are modified with the breath. Other tribes in Borneo use a bamboo one; this was no doubt the origin of the Dyak one; the Maloh have taught the Dyaks the use of metal. Bamboo ones are not now in use among them. The case in which it is kept is a bamboo cylinder beautifully carved; the ground is coloured red with dragon's blood; girth about $2 \frac{1}{4}$ inches, fitted with a carved hard-wood stopper. The metal is not flat, but almost imperceptibly concave.

Serunai is made of a hollow gourd, selaing, with a hole, and is one-stringed (segu cane), and is played with a bow, the string of which is of same material. The performer sits on the ground and holds the instrument between his toes, the knees bending outward, and the soles of his feet adjoining. The sound is that of a violin played with a bow, and is mournful, wailing, sobbing, heartrending, dismal, and gloomy. The instrument is held slanting, and the sounding cup on the side of the foot, with the stem resting on the left shoulder. The string must be watered with saliva to sound. The stock is 2 feet long, and of hardwood (bilian). The cup is 12 inches in circumference, and is a gourd shell, called geno-selaing, about the size of a teacup, and with a hole at the bottom. The mouth of it is covered up with a circular dish of soft wood, thin and close-fitting, and the seams cemented with wild wax. The bow is a bent cane, and the string a split rattan nearly 12 inches long. There is a moveable bridge on the dish for the string to rest upon. Sometimes the bowl is made of coco-shell.

The blikan is a rude-stringed instrument resembling a guitar, 
and was formerly much in use. It was adopted from the Urus, and is more frequently found among the Seribas and Kalakan Dyaks than among any others. It is furnished with two strings (rattan) and two keys. The strings are pressed with the tips of the fingers of the left hand to modify the tone--there are no stops-while the nails of the fingers of the right hand brush the strings. The stock is glued into the beak or bill of a bird, the kinalong or burong bileh, and the body is coloured red with the colouring matter of a wild-growing, poisonous fungus. It is 3 feet long from end to end. The blikan is hollowed out from the upper surface, and is covered with a thin plate of wood. The safe, on the other hand, is hollowed out from underneath, and is not closed up.

The gendang is a wooden drum, shaped like an hour glass, one end covered with parchment, which can be tightened or slackened at pleasure, by means of cords ; it is not beaten with drumsticks, but is struck with the fingers.

The satong is a cylindrical bamboo harp, or lyre, played upon with the fingers.

The gulieng is a bamboo pipe, with a plug at the mouth hole, and differs from a whistle in having finger holes, by means of which different tones can be produced. It is blown at the end like a flageolet, and the three finger holes are placed equidistantly. Four distant tones are easily obtainable upon it, the lowest when all the finger holes are covered, and the other three by opening the finger holes successively.

The krumong is made of narrow slabs of wood or stone, which upon percussion with a wooden hammer produce a series of tones similar to those obtained on an harmonicon.

The busoi is formed of a bow resting on the ground in a hollow vessel of earthenware or metal, and the string is made to vibrate with a plectrum.

The kilırai is a wind instrument, constructed of a number of tubes, placed in a calabash with a long snout which serves as a mouthpiece, and which are thus sounded together; chords and combinations of chords or harmony can be produced from it. The finger holes are, some of them, placed laterally, others on the upper surface, and others again on the lower surface.

Singing.-The pelandai is the recitative in which the natives pour forth their feelings, their sorrows and disappointments, their desires and ambitions. It is full of feeling, and the voice is modulated to express all its shades. The utterance is slow at first, but is rapid towards the end. There is repetition in redundancy of expression and reiteration. The voice is often tremulous with passion, like the wail of a broken heart-a mournful cadence like the dirge of the dead. 
Very different are their war songs. The bard leading the song, chants in a low monotonous solo, his voice rising and falling as he chants of love or war, and is accompanied by the whoops, and yells (fierce, exultant, presumptuous, and cheering) of his companions, and by the clashing of shields and nodding of plumes as the warriors, in their excitement, don their feathers and seize their arms, singing of the deeds of heroes of the olden days and lovely women whose charms gave rise to deadly strife and bloody feuds. These songs have the same effect on the natives of Borneo that the war drum and trumpetblast have on the soldiers of Europe. The tones of tha minstrel are clear, and bold, and tremulous, and culminating at times in a prolonged chorus which the others take up with sumething like a prolonged yell.

[To be concluded.]

MARCH 8TH, 1892.

Edward B. Tylor, Esq., D.C.L., F.R.S., President, in the Chair.

The Minutes of the last meeting were read and signed.

The following presents were announced, and thanks roted to the respective donors:-

For 'iHe Library.

From the AUtHoR.-Yorkshire Folk-Talk. By the Rer. M. F. C. Morris, B.C.L., M.A. 8vo. London, 1892. pp. xii, 408.

- Vocabularies of the Tlingit, Haida, and Tsimshian Languages. By Dr. Franz Boas. 8vo. pp. 36.

Aboriginal Skin Dressing. By Otis T. Mason. 8ro. pp. 37. Plates.

- The Development of the American Rail and Track, as illustrated by the Collection in the U.S. National Museum. By J. Elfreth Watkins. 8vo. pp. 58. Woodcuts.

- Te Pito te Henua, or Easter Island. By William J. Thomson. 8vo. pp. 108. Illustrated.

- Projet d'entente internationale pour arrêter un programme commun de recherches Anthropologiques a faire aux conseils de révision. By Dr. R. Collignon. 8vo. pp. 11.

Estudio sobre el sistema evolucionista. By Emilio Cuervo. 8vo. Bogotá (Colombia), 1891. pp. 73. 